\title{
CANOLA AGRONOMIC PERFORMANCE IN THREE SOWING DATES IN JATAÍ-GO
}

\author{
DESEMPENHO AGRONÔMICO DA CANOLA EM TRÊS ÉPOCAS DE SEMEADURA \\ EM JATAÍ-GO
}

\author{
Raissa Macedo ASSIS'; Flavia Andrea Nery SILVA²; Luciana Celeste CARNEIRO; \\ Givanildo Zildo da SILVA ${ }^{3}$; Simério Carlos Silva CRUZ; ; Carla Gomes MACHADO $^{3}$ \\ 1. Postgraduate Program in Agronomy, Federal University of Jataí - UFJ, Jataí, GO, Brazil. rmacedoassis@gmail.com; \\ 2. Institute of Agricultural Sciences, Federal University of Uberlândia, Uberlândia, MG, Brazil; \\ 3. Department of Agronomy, Postgraduate Program in Agronomy, Federal University of Jataí, Jataí, GO, Brazil;
}

\begin{abstract}
Canola (Brassica napus L. var oleifera) is a potential crop due to the growing world demand for vegetable oil. This work aims to evaluate the performance of five canola hybrids in three sowing dates in Jataí-GO. The experiment was conducted in the year of 2017, in a randomized block design, with subdivided plots and four replications. Plots were composed by three sowing dates (03/03, 03/10 and 03/17) and subplots by the canola hybrids Hyola 50, Hyola 61, Hyola 433, Hyola 571CL and Hyola 575CL. Seedling emergence, inicial and final plant population, flowering, maturation, plant height, plant survival index and grain yield were evaluated. The thermal sum calculation was performed with the phenological data. Results were submitted to analysis of variance and means were compared by Scott Knott test at $5 \%$ of probability. The plants survival index highlighted Hyola 433, Hyola 571CL and Hyola 575CL hybrids. Grain yield varied according to hybrid and sowing date. In the edaphoclimatic conditions of this study, in the year of 2017, the best agronomic performance was observed in the first sowing date for the canola hybrids Hyola 433 and Hyola 575CL and in the second sowing date for the canola hybrid Hyola 571CL.
\end{abstract}

KEYWORDS: Brassica napus L. var oleífera. Phenology. Productivity. Tropicalization.

\section{INTRODUCTION}

Canola (Brassica napus L. var. Oleifera) is one of the most important oilseeds in the world and one of the main sources of edible vegetable oil, being preferred because its low saturated fatty acid content (TAN et al., 2009). Over the past 40 years global canola production has grown rapidly, ranking from sixth to second most produced oilseed crop in the world (USDA, 2017).

The main canola growers are European Union, Canada, China, India, and Australia (USDA, 2017), all of them located at high latitudes, between $35^{\circ}$ and $55^{\circ}$. In Brazil, research on canola cultivation began in 1974 in Rio Grande do Sul State and in the 1980 s in Paraná State, where it was grown the spring specie, Brassica napus, since it does not require vernalization and has low photoperiod sensitivity (MORI et al., 2014; TOMM et al., 2009b).

Canola plant is originally adapted to mild conditions and regularly distributed rain throughout its growth period (MENDONÇA et al., 2016). Genotypes cultivated in Brazil present lower photoperiod sensitivity and higher response to air temperature (thermal sum) instead of rapeseed open pollination varieties grown in the past
(MONTEIRO, 2009). The air temperature is the most important environmental factor in regulating canola growth and development (THOMAS, 2003).

Commercial crops in Brazil are concentrated in the southern region. According to CONAB (2018), an average yield of $1,358 \mathrm{~kg} \mathrm{ha}^{-1}$ is expected and a 48 thousand tons production in 35.5 thousand hectares area. Canola cultivation is expanding to lower latitudes in Brazil, a process called tropicalization. There was a commercial crop in Goiás, in 2004, partially encouraged by the results of a trial in five different places, in which it was obtained grain yields from 2,100 and 2,400 kg $\mathrm{ha}^{-1}$. In the southwest Goiás, canola crop can be an alternative for diversification and income generation as a second harvest (EMBRAPA, 2017).

Brazilian demand for canola crop is a great incentive for research works, considering that there are limited technical scientific information regarding crop management in Brazil especially in low latitude regions. The highest grain yield is obtained when canola is cultivated at $17 \mathrm{~cm}$ between rows and density of 45 plants per square meter. Best yield results were observed by spacing rows until 45 cm (BANDEIRA et al., 2013; TOMM, 2007).

According to Mendonça et al. (2016) the best sowing period recommended for Goiás State is 
from early February to mid-March, respecting agricultural zoning indications by the country's agriculture department (BRASIL, 2012).

Although its importance as an alternative crop in Brazil's Midwest, there are few studies on canola cultivation at that important agricultural area, considering the most adapted hybrid to that edaphoclimatic condition and the best sowing dates. This work aims to evaluate the performance of five canola hybrids in three sowing dates in Jataí-GO.

\section{CONTENTS}

Trial was carried out at the experimental farm of Federal University of Jataí, located at $17^{\circ} 55$
'25' 'S and $51^{\circ} 42^{\prime} 51$ " W, and $696 \mathrm{~m}$ of altitude. According to Köppen climatic classification, it is located at a tropical savanna area, Aw, mesothermic, with a rainy summer and an expressive drought winter. Local soil is classified as Dystroferric Red Latosol.

Local climatic data during the canola crop development (March to July 2017) was obtained from a national meteorological station (INMET conventional database) (Figure 1). The experimental design was the randomized block and treatments were arranged in a subdivided plots scheme with four replications. Plots were composed by three sowing dates and subplots by five canola hybrids

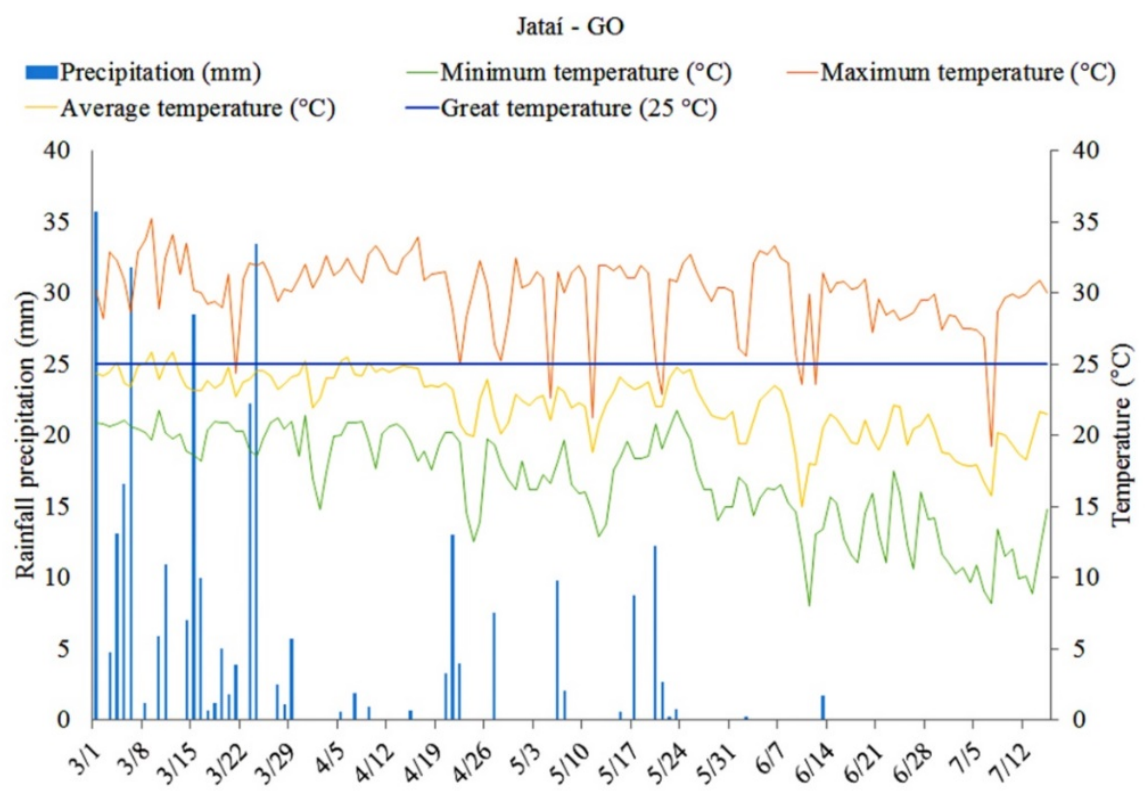

Figure 1. Precipitation (mm), minimum, average and maximum temperature $\left({ }^{\circ} \mathrm{C}\right)$ from March to July of 2017 in Jataí-GO. Source: INMET (2017).

An uniform plot of $843.75 \mathrm{~m}^{2}$ was selected and rice straw was incorporated to soil by the conventionally tillage system.
Sowing was carried out with Hyola 50, Hyola 61, Hyola 433, Hyola 571CL and Hyola $575 \mathrm{CL}$ canola hybrids (Chart 1 ), in the following sowing dates: 03/03, 03/10 and 03/17, 2017.

Chart 1. Main characteristics of canola hybrids sowed in the experiment.

\begin{tabular}{|l|c|c|}
\hline Hybrids & Cycle & Characteristics \\
\hline Hyola 50 & Medium & $\begin{array}{c}\text { Indicated for planting in opening areas and in combination with other } \\
\text { hybrids. High yield potential. }\end{array}$ \\
\hline Hyola 61 & Medium & Yield stability and rusticity under dry stress and frost. \\
\hline Hyola 433 & Early & $\begin{array}{c}\text { Indicated for succession with maize crop. Requires high fertility soils to } \\
\text { express its potential. }\end{array}$ \\
\hline Hyola 571CL & Early & Resistant to imidazolinones group herbicides. \\
\hline Hyola 575CL & Early & Resistant to imidazolinones group herbicides. \\
\hline
\end{tabular}

Source: Adapted from Tom and Ferreira (2016). 
Each plot consisted of five sowing lines, five meters each, $0.45 \mathrm{~m}$ spacing and 62 seeds per $\mathrm{m}^{2}$. Sowing was handy done by the adhesive tape technique. In the laboratory, seeds were arranged in an adhesive tape, which were later taken to the field and placed in the planting line, previously prepared by an automatic planter.

Planting fertilization was done by $30 \mathrm{~kg} \mathrm{ha}^{-1}$ of $\mathrm{N}, 60 \mathrm{~kg} \mathrm{ha}^{-1}$ of $\mathrm{P}_{2} \mathrm{O}_{5}$ and $50 \mathrm{~kg} \mathrm{ha}^{-1}$ of $\mathrm{K}_{2} \mathrm{O}$ applied in the soil surface, using as source, urea, triple superphosphate and chloride potassium, respectively. When seedlings were in rosette stage, $50 \mathrm{~kg} \mathrm{ha}^{-1}$ of nitrogen fertilizer was applied, using ammonium sulfate as source of N. Fertilization was performed according to results obtained from soil analysis and from the brasilian agricultural research company's recommendations (TOMM, 2007) for canola cultivation.

During crop development, hand weeding, herbicides and insecticides were used for the control of weeds, Myzus persicae, Brevicoryne brassicae, Diabrotica speciosa and Ascia spp.

Hybrids performance and sowing date influence were evaluated by the following phenological and phenometric variables:

Seedlings emergence - when $50 \%$ of seedlings were emerged in each plot; Initial plant population - based on the number of plants in a row (4 meters long), one month after sowing; Flowering - when $50 \%$ of plants had at least one flower; Maturation - when $50 \%$ of seeds changed to dark color in pods located in the middle of the plant's main raceme; Plant height - using a graduated ruler, plant height was measured from soil surface to the top of the largest raceme with pods; Final plant population - based on the number of plants harvested in the useful area $\left(4.05 \mathrm{~m}^{2}\right.$ on each subplot); Grain yield - grains from useful area were harvested, weighed and moisture was determined and corrected to canola moisture reference of $9 \%$ for yield calculation; Plants survival index was calculated by the survival percentage from early to late plant population. The accumulated thermal sum calculation was performed from the phenological data according to Arnold (1960): $\mathrm{TS}=\Sigma \mathrm{TSd}$

$\mathrm{TSd}=\mathrm{Ta}-\mathrm{Tb}$; on what:

$\mathrm{TS}=$ accumulated thermal sum;

$\mathrm{TSd}=$ daily thermal sum;

$\mathrm{Ta}=$ Average air temperature;

$\mathrm{Tb}=$ basal temperature.

The basal temperature of $5{ }^{\circ} \mathrm{C}$ was considered as indicated by Morrison et al. (1989), Nanda et al. (1995), Iriarte and Valetti, (2008) and Dalmago et al. (2009). The thermal sum was obtained for the following development subperiods: emergence to early flowering (EM-EF), early to late flowering (EF-LF) and emergence to physiological maturation (EM-PM).

Data were submitted to analysis of variance and means were compared by Scott Knott test at 5\% of probability.

Table 1 shows the results of the analysis of variance for initial and final plant population, plants survival index, days between emergence to early flowering (EM-EF), early to late flowering (EF-LF) emergence to physiological maturation (EM-PM), thermal sum for each subperiod expressed in degree-day, plant height, and grain yield of five canola hybrids, in three sowing dates.

Table 1. Summary of analysis of variance (F value) for initial plant population (IPP), final plant population (FPP), plants survival index (PSI), thermal sum expressed in degree-day (DD) and subperiods duration in days (days) between emergence to early flowering (EM-EF), early to late flowering (EF$\mathrm{LF}$ ) emergence to physiological maturation (EM-PM), plant height (PH) and grain yield (GY) of five canola hybrids in three sowing dates.

\begin{tabular}{|c|c|c|c|c|c|c|c|c|c|c|c|c|}
\hline $\begin{array}{l}\text { Variation } \\
\text { Source }\end{array}$ & DF & IPP & FPP & PSI & $\begin{array}{c}\text { EM-EF } \\
\text { (DD) }\end{array}$ & $\begin{array}{c}\text { EM-EF } \\
\text { (days) }\end{array}$ & $\begin{array}{l}\text { EF-LF } \\
\text { (DD) }\end{array}$ & $\begin{array}{l}\text { EF-LF } \\
\text { (days) }\end{array}$ & $\begin{array}{c}\text { EM-PM } \\
\text { (DD) }\end{array}$ & $\begin{array}{l}\text { I EM-PM } \\
\text { (days) }\end{array}$ & $\begin{array}{l}\mathrm{PH} \\
(\mathrm{cm})\end{array}$ & GY \\
\hline Bloc & 3 & $6.3^{*}$ & $0.8^{\mathrm{ns}}$ & $0.4^{\mathrm{ns}}$ & $0.6^{\mathrm{ns}}$ & $4.5^{\mathrm{ns}}$ & $1.5^{\mathrm{ns}}$ & $0.4^{\mathrm{ns}}$ & $2.64^{\mathrm{ns}}$ & $1.3^{\mathrm{ns}}$ & $1.5^{\mathrm{ns}}$ & $0.9^{\mathrm{ns}}$ \\
\hline Date (D) & 2 & $48.0^{* * * *}$ & $25^{* *}$ & $3.0^{\mathrm{ns}}$ & $1.2^{\mathrm{ns}}$ & $15.3^{* *}$ & $3.6^{\mathrm{ns}}$ & $3.4^{\mathrm{ns}}$ & $74.76^{* *}$ & $13.2^{* *}$ & $6.5^{*}$ & $9.67^{*}$ \\
\hline$d(H)$ & 4 & $32.6^{* * *}$ & $50.5^{* * *}$ & $25.6^{* * *}$ & $51.5^{* * *}$ & $134.3^{* * *}$ & $11.7^{* * *}$ & $21.9^{* * *}$ & $35.53^{* * *}$ & $10.73^{*}$ & $0.86^{\mathrm{ns}}$ & $15.4^{* * *}$ \\
\hline $\mathrm{D} \times \mathrm{H}$ & 8 & $11.3^{* * *}$ & $5.1^{* * * *}$ & $3.3^{* *}$ & $1.5^{\mathrm{ns}}$ & $6.37^{* * * *}$ & $1.1^{\mathrm{ns}}$ & $2.2^{\mathrm{ns}}$ & $3.0^{*}$ & $1.3^{\mathrm{ns}}$ & $1.0^{\mathrm{ns}}$ & $7.5^{* * *}$ \\
\hline CV D (\%) & & 6.90 & 15.37 & 15.97 & 7.46 & 3.01 & 9.95 & 10.63 & 1.55 & 5.68 & 6.54 & 17.08 \\
\hline V H (\%) & & 9.37 & 9.96 & 11.33 & 8.54 & 5.98 & 11.80 & 8.25 & 2.40 & 5.24 & 5.22 & 15.70 \\
\hline
\end{tabular}

$*, * *, * * *,{ }^{\text {ns }}$ : significant at $0,05,0,01,0,001$ probability and not important $(\mathrm{p}>=0,05)$ by $\mathrm{F}$ test, respectively DF: Degrees of freedom. $\mathrm{CV}$ : coefficient of variation. 
There was interaction between hybrids and sowing dates for initial and final population, plants survival index, days between emergence to early flowering, days between emergence to physiological maturation, and grain yield. For the emergence to early flowering and for the early to late flowering thermal sum, there was only hybrid significant effect, as well as for days from the early to late flowering. Regarding the days between emergence to physiological maturation, there was no interaction, but there was hybrid and date effect. For plant height there was no interaction, except for sowing dates effect.

Table 2 shows the interaction between hybrid and sowing dates for the variable initial plant population.

Table 2. Initial plant population (plants $\mathrm{ha}^{-1}$ ) of five canola hybrids in three sowing dates.

\begin{tabular}{|c|c|c|c|}
\hline \multirow{3}{*}{ Hybrids } & \multicolumn{3}{|c|}{ Sowing date } \\
\hline & $03 / 03$ & $03 / 10$ & $03 / 17$ \\
\hline & \multicolumn{3}{|c|}{ Initial plant population (plants $\mathrm{ha}^{-1}$ ) } \\
\hline Hyola 50 & $320,367 \mathrm{bB}$ & $468,051 \mathrm{aA}$ & $340,738 \mathrm{aB}$ \\
\hline Hyola 61 & $266,664 \mathrm{cA}$ & $305,553 \mathrm{cA}$ & $187,035 \mathrm{~dB}$ \\
\hline Hyola 433 & $370,367 \mathrm{aA}$ & $301,386 \mathrm{cB}$ & $253,701 \mathrm{cC}$ \\
\hline Hyola 571CL & $407,402 \mathrm{aA}$ & $338,886 \mathrm{bB}$ & $349,997 \mathrm{aB}$ \\
\hline Hyola 575CL & $281,479 \mathrm{cB}$ & $351,848 \mathrm{bA}$ & $294,442 \mathrm{bB}$ \\
\hline
\end{tabular}

Means followed by the same lowercase letter in the column and upper case in the row do not differ statistically from each other according to Scott-Knot test at 0.001 probability.

Considering the different sowing dates, Hyola 50 and Hyola 575CL, sowed on $03 / 10$ allowed a larger initial plant population, with 468,051 and 351,848 plants ha $^{-1}$, respectively. For Hyola 61, there was no significant difference between the first and second date, 266,664 and 305,553 plants $\mathrm{ha}^{-1}$, respectively, while Hyola 433 presented better performance in the first date, 370,367 plants $\mathrm{ha}^{-1}$. In relation to hybrid performance, Hyola 571CL and Hyola 433 were highlighted in the first date. In the second date, Hyola 50 presented the highest initial population, 468,051 plants $\mathrm{ha}^{-1}$. There was no statistical difference between Hyola 50 and Hyola 571CL in the third sowing date.

One of the biggest challenges for canola growers is the stand establishment. Several factors affect seed mortality and seedling emergence, such as soil moisture, soil texture and temperature, seeding depth, diseases, insects, and climatic factors (HANSON et al., 2008).

Planting depth is a seedling emergence important factor. According to Tomm et al. (2009a), seeds should be evenly deposited at $1-2 \mathrm{~cm}$, and they should remain on the moist soil surface, rather than very deep. Possibly, seeds physiological quality and sowing depth are decisive for initial plants population. The establishment of a proper canola population is essential to achieve high grain yield (SHAHIN; VALIOLLAH, 2009).

Final plant population (Table 3), in general, was lower than initial plant population and below expectations. The largest final population observed was for Hyola 433 in the first date, with 316,046 plants ha ${ }^{-1}$, and the lowest was for Hyola 61 in the third date, with 127,571 plants ha ${ }^{-1}$.

Table 3. Final plant population (plants $\mathrm{ha}^{-1}$ ) of five canola hybrids in three sowing dates.

\begin{tabular}{lccc}
\hline & \multicolumn{3}{c}{ Sowing dates } \\
\cline { 2 - 4 } Hybrids & $03 / 03$ & $03 / 10$ & $03 / 17$ \\
\cline { 2 - 4 } & $197,529 \mathrm{cB}$ & Final plant population $\left(\right.$ plants ha $\left.{ }^{-1}\right)$ \\
\hline Hyola 50 & $155,554 \mathrm{~dB}$ & $197,515 \mathrm{aA}$ & $160,492 \mathrm{bB}$ \\
Hyola 61 & $316,046 \mathrm{aA}$ & $270,985 \mathrm{aB}$ & $127,571 \mathrm{bB}$ \\
Hyola 433 & $306,170 \mathrm{aA}$ & $298,762 \mathrm{aA}$ & $190,122 \mathrm{aC}$ \\
Hyola 571CL & $232,096 \mathrm{bB}$ & $270,779 \mathrm{aA}$ & $223,866 \mathrm{aB}$ \\
Hyola 575CL & & $214,813 \mathrm{aB}$ \\
\hline
\end{tabular}

Means followed by the same lowercase letter in the column and upper case in the row do not differ statistically from each other according to Scott-Knot test at 0.001 probability.

In general, the first and second dates presented better results for final plant population. In the first sowing date, Hyola 433 and Hyola 571CL stood out, with 316,046 and 306,170 plants $\mathrm{ha}^{-1}$, 
respectively. In the second date, Hyola 61 differed from the others with the lowest final population, and in the third date, there was no statistical difference between Hyola 433, Hyola 571CL and Hyola $575 \mathrm{CL}$.

Arruá et al. (2014), evaluating the agronomic characteristics of Hyola 61 and Hyola 433 , observed an average number of 252,500 plants $\mathrm{ha}^{-1}$, lower than it was expected, about 488,888
ASSIS, R. M. et al.

plants $\mathrm{ha}^{-1}$. It is recommended, according to Chavarria et al. (2011), a uniform plant population of 450,000 plants ha $^{-1}$ to guarantee hybrids yield potential.

Table 4 presents the variable plants survival index, which is the difference between the initial and final plant population, and it was possible to observe that there was interaction between hybrids and sowing dates.

Table 4. Plants survival index (\%) of five canola hybrids in three sowing dates.

\begin{tabular}{lccc}
\hline & \multicolumn{3}{c}{ Sowing dates } \\
\cline { 2 - 4 } Hybrids & $03 / 03$ & $03 / 10$ & $03 / 17$ \\
\cline { 2 - 4 } & & Plants survival index (\%) \\
\hline Hyola 50 & $61.76 \mathrm{bA}$ & $53.35 \mathrm{cA}$ & $47.62 \mathrm{bA}$ \\
Hyola 61 & $57.99 \mathrm{bA}$ & $65.07 \mathrm{cA}$ & $70.03 \mathrm{aA}$ \\
Hyola 433 & $85.60 \mathrm{aA}$ & $89.84 \mathrm{aA}$ & $75.39 \mathrm{aA}$ \\
Hyola 571CL & $75.36 \mathrm{aB}$ & $88.51 \mathrm{aA}$ & $64.02 \mathrm{aB}$ \\
Hyola 575CL & $82.45 \mathrm{aA}$ & $77.03 \mathrm{bA}$ & $74.07 \mathrm{aA}$ \\
\hline
\end{tabular}

Means followed by the same lowercase letter in the column and upper case in the row do not differ statistically from each other according to Scott-Knot test at 0.01 probability.

Plants survival index was not influenced by sowing date for Hyola 50, Hyola 61, Hyola 433 and Hyola 575CL. For Hyola 571CL, the second date presented higher index than the others.

In the first sowing date, hybrids Hyola 433, Hyola 571CL and Hyola 575CL stand out. In the second, there was no difference between Hyola 433 and Hyola 571CL. In the third date, Hyola 50 differed from the other hybrids with lower survival.

Considering the difference of initial and final plant population (plants survival index), it is recommended the use of more seeds in sowing, with high physiological quality and it also should be considered the local altitude, because these factors may interfere in plant's survival index, which influences the appropriate final stand.

For the phenological observations, there was interaction between hybrids and sowing date for the variable days between emergence to early flowering. However, when evaluating the thermal sum, in degree-day, there was difference only between hybrids (Table 5).

Table 5. Emergence to early flowering in degree-day and days of five canola hybrids in three sowing dates.

\begin{tabular}{lcccc}
\hline \multirow{2}{*}{ Hybrids } & \multicolumn{3}{c}{ Days } & \multirow{2}{*}{ Degree-day } \\
\cline { 2 - 4 } & \multicolumn{3}{c}{ Sowing date } & \\
\cline { 2 - 4 } & $03 / 03$ & $03 / 10$ & $60 \mathrm{aB}$ & $1102 \mathrm{a}$ \\
\hline Hyola 50 & $56 \mathrm{aC}$ & $68 \mathrm{aA}$ & $44 \mathrm{bA}$ & $858 \mathrm{~b}$ \\
Hyola 61 & $46 \mathrm{bA}$ & $44 \mathrm{bA}$ & $43 \mathrm{bA}$ & $748 \mathrm{c}$ \\
Hyola 433 & $38 \mathrm{cB}$ & $38 \mathrm{cB}$ & $42 \mathrm{bA}$ & $777 \mathrm{c}$ \\
Hyola 571CL & $40 \mathrm{cA}$ & $41 \mathrm{bA}$ & $42 \mathrm{bA}$ & $748 \mathrm{c}$ \\
Hyola 575CL & $39 \mathrm{cA}$ & $38 \mathrm{cA}$ & \\
\hline
\end{tabular}

Means followed by the same lowercase letter in the column and upper case in the row do not differ statistically from each other according to Scott-Knot test at 0.001 probability.

For days between emergence to early flowering, Hyola 50 and Hyola 433 were the only ones that showed differences for the sowing date. For Hyola 50 a longer period is observed in the second sowing date, 68 days. For Hyola 433, it was longer in the third date, with 43 days. In all sowing dates, Hyola 50 hybrid stands out with the longest period between emergence to early flowering, with 56, 68 and 60 days for first, second and third sowing dates, respectively. In the first date, there was no difference between Hyola 433, Hyola 571CL and Hyola 575CL, with shorter vegetative period. In the second, Hyola 433 and Hyola 575CL also presented a shorter period, and in the third only Hyola 50 was 
different from the others, with 60 days. Due to climatic conditions, a short vegetative period is beneficial. The higher precocity for the early flowering, that is, short vegetative period, is important in environments where water deficit is accentuated at the end of the crop cycle (NIED, 2013).

Nied (2013), evaluating Hyola 61 and Hyola 432 hybrids in Passo Fundo - RS, observed that during the vegetative period canola required 526 and 629 degrees-day in 63 and 69 days in 2010 and 2011, respectively. In the present work, hybrids presented a shorter period in days, however, the thermal sum needed to complete it was higher, in which Hyola 61 required 858 degree-day in 46 days for the first date, and 44 days for the second and third sowing dates.

The highest thermal sums observed are due to the high air temperature. Parts of these high air temperature values are counted in the thermal sum, but do not contribute to the crop development, since they are above the optimal canola values (NIED, 2013). The ideal temperature ranges from 12 to 30 ${ }^{\circ} \mathrm{C}$ and the growth optimum temperature is $25^{\circ} \mathrm{C}$, with thermal stress above it (EDWARDS; HERTEL, 2011; MENDONÇA et al., 2016).

Luz et al. (2012) observed that for Hyola 61 and Hyola 433 in Santa Maria - RS, the vegetative period last from 52 to 78 days and from 49 to 76 days, respectively, according to the sowing date.

The overall average temperature from emergence to early flowering was $24.1^{\circ} \mathrm{C}$, with the maximum reaching $31{ }^{\circ} \mathrm{C}$. The precipitation was more concentrated until the end of March, with an average of $127.7,124.24$ and $90.5 \mathrm{~mm}$ in this subperiod from emergence to early flowering for each date (Figure 1). According to Tomm et al. (2014), in general, smaller durations of these subperiods occur at higher temperatures and lower altitude, conditions of the present experiment.

In relation to early to late flowering duration in degree-day and days, there was no interaction between hybrids and sowing dates, with significant effect only for hybrids (Table 6). For emergence to physiological maturation in days, there was no interaction between those factors, with significant effect for hybrids (Table 6) and sowing dates (Table 7).

Table 6. Early to late flowering (days), early to late flowering (degree-day) and emergence to physiological maturation (days) of five canola hybrids.

\begin{tabular}{lccc}
\hline Hybrid & $\begin{array}{c}\text { Early to late flowering } \\
\text { (days) }\end{array}$ & $\begin{array}{c}\text { Early to late flowering } \\
\text { (degree-day) }\end{array}$ & $\begin{array}{c}\text { Emergence to } \\
\text { physiological maturation } \\
\text { (days) }\end{array}$ \\
\hline Hyola 50 & $34 \mathrm{c}$ & $566 \mathrm{c}$ & $104 \mathrm{a}$ \\
Hyola 61 & $45 \mathrm{a}$ & $760 \mathrm{a}$ & $97 \mathrm{~b}$ \\
Hyola 433 & $44 \mathrm{a}$ & $769 \mathrm{a}$ & $94 \mathrm{~b}$ \\
Hyola 571CL & $41 \mathrm{~b}$ & $698 \mathrm{~b}$ & $94 \mathrm{~b}$ \\
Hyola 575CL & $42 \mathrm{~b}$ & $697 \mathrm{~b}$ & $92 \mathrm{~b}$ \\
\hline
\end{tabular}

Means followed by the same letter in the columm do not differ statistically from each other according to Scott-Knot test at 0.001 probability.

Hyola 50 was different from the other hybrids, with lower early to late flowering duration, 34 days, and lower thermal sum, 566 degrees-day. Hyola 61 and Hyola 433 presented the early to late flowering duration longer and a bigger thermal sum.

In Santa Maria - RS, Hyola 61 and Hyola 433 early to late flowering duration ranged from 34 to 81 days, according to sowing date (LUZ et al., 2012). Nied (2013) observed that in the reproductive period the average thermal sum was 823 and 846 degree-day at 79 and 63 days, in 2010 and 2011, respectively, considering the average thermal sum for each year, for both Hyola 432 and Hyola 61 hibrids.

The flowering duration ranged from 34 to 45 days for Hyola 50 and Hyola 6 respectively and it was required less thermal accumulation from 566 degree-day for Hyola 50 and 769 degree-day for Hyola 433. The early to late flowering duration in days, and the thermal accumulation were lower due to high air temperatures above $25{ }^{\circ} \mathrm{C}$ (Figure 1), which reduce the flowering and maturation period (MENDONÇA et al., 2016).

According to Tomm (2007), the long flowering period is typical of canola, and can vary from 20 to 45 days, which compensates the flowers loss. During the flowering period, temperatures above $27^{\circ} \mathrm{C}$ are harmful because they reduce the phase duration and can affect pollen viability and flowers receptivity, resulting in grain yield reduction, about $50 \%$, due to the flowers abortion (ANGADI et al., 2000; MENDONÇA et al., 2016). In the present experiment, the maximum temperature that occurred in this period was $31^{\circ} \mathrm{C}$. 
For emergence to physiological maturation (days), Hyola 50 differed from the other hybrids presenting a longer cycle, with 104 days duration. The other hybrids did not present statistical difference, ranging from 92 days for Hyola 575CL, 94 days for Hyola 433 and Hyola 571CL and 97 days for Hyola 61. Luz et al. (2012), in Santa Maria - RS, observed 134 days duration for Hyola 433 and 147 for Hyola 61. In the same study it was evaluated the relative development of plants according to air temperature, it was concluded that a negative linear relationship between air temperature and cycle duration indicates that the decrease in air temperature determines an increase in cycle durations and subperiods for the two genotypes.

There was a statistical difference to the sowing date for emergence to physiological maturity in days and average plant height (Table 7). For emergence to physiological maturation in days, it was observed that, the later the sowing date, the bigger the plant cycle.

Hrchorovitch et al. (2014), evaluating six sowing dates in Dois Vizinhos - PR, observed a bigger canola cycle in later sowing dates until the fourth date, for Hyola 61, Hyola 76, Hyola 411 and Hyola 433. For the two later dates, there was a decline in cycle length.

Table 7. Emergence to physiological maturation (days) and average plant height $(\mathrm{m})$ in three sowing dates.

\begin{tabular}{lcc}
\hline Date & Emergence to maturation (days) & Average plant height $(\mathrm{m})$ \\
\hline $03 / 03$ & $92 \mathrm{c}$ & $1.12 \mathrm{a}$ \\
$03 / 10$ & $96 \mathrm{~b}$ & $1.05 \mathrm{~b}$ \\
$03 / 17$ & $101 \mathrm{a}$ & $1.12 \mathrm{a}$ \\
\hline
\end{tabular}

Means followed by the same letter in the column do not differ statistically from each other according to Scott-Knot test at 0.001 probability.

The air temperature is the meteorological element that most influences plants phenology and development (STRECK, 2002) and, therefore, the cycle duration can be affected by lower and higher critical limits of air temperature for the crop, being able to promote alterations in the development of plant subperiods duration and in the plant total cycle.

Plants average height varied according to sowing date, $1.12 \mathrm{~m}$ in the first and third dates and
$1.05 \mathrm{~m}$ in the second. Rigon et al. (2017), evaluating Hyola 433, Hyola 50, Hyola 61, Hyola 76, Hyola 571CL and Hyola 575CL in two sowing dates in Santa Maria - RS, reported that canola hybrids sown in the first date showed higher values for this variable.

For emergency to physiological maturation in degree-day there was interaction between hybrids and date (Table 8).

Table 8. Emergency to physiological maturation in degree-day of five canola hybrids in three sowing dates.

\begin{tabular}{lccc}
\hline \multirow{2}{*}{ Hybrids } & \multicolumn{3}{c}{ Sowing date } \\
\cline { 2 - 4 } & $03 / 03$ & $03 / 10$ & $03 / 17$ \\
\hline Hyola 50 & $1720 \mathrm{aB}$ & $1814 \mathrm{aA}$ & $1856 \mathrm{aA}$ \\
Hyola 61 & $1676 \mathrm{aB}$ & $1731 \mathrm{bB}$ & $1864 \mathrm{aA}$ \\
Hyola 433 & $1628 \mathrm{bB}$ & $1633 \mathrm{cB}$ & $1701 \mathrm{bA}$ \\
Hyola 571CL & $1661 \mathrm{aA}$ & $1668 \mathrm{cA}$ & $1689 \mathrm{bA}$ \\
Hyola 575CL & $1613 \mathrm{bB}$ & $1604 \mathrm{cB}$ & $1686 \mathrm{bA}$ \\
\hline
\end{tabular}

Means followed by the same lowercase letter in the column and upper case in the row do not differ statistically from each other according to Scott-Knot test at 0.001 probability.

In general, the later the sowing date, the bigger the thermal sum needed to complete the cycle; however, this is dependent on the hybrid. Hyola 571CL was the only hybrid that did not present statistical difference of the thermal sum between the three dates, varying from 1,661 degreeday for first date and 1,689 for the third. Hyola 61, Hyola 433 and Hyola 575CL showed the highest sum in the last sowing date, with 1,864, 1,701 and 1,686 degree-day, respectively.

Thermal sums obtained in the total canola cycle resemble those found by Fochesatto (2012), 1,674 degree-day, who worked with different canola genotypes in two Rio Grande do Sul municipalities. Equivalent results were also observed by Luz et al. (2012) for Hyola 433 and Hyola 61, which were 1,515 and 1,644 degree-day, respectively. 
Tesfamarian (2004), in a work conducted in Africa with Hyola 60, also reported similar value, 1,742 degree-day.

The most important effect of air temperature lies on the canola plant stages definition. Each stage progresses from a certain amount of temperature accumulation, expressed by degree-day index (DALMAGO et al., 2009). Thus, at elevated temperatures, there is an increase in the metabolic process, which shortens the plant cycle, reducing its height.

Although the number of days is an indicator for definition of canola crop cycle, it should be remembered that it is a form that presents great variability, and the rate of plant development responds to the air temperature, defining, then, the phenological stages. The increase in temperature accelerates the plant growth stages, which can cause great difference in terms of total cycle, shortening it (MENDONÇA et al., 2016; DALMAGO et al., 2009). High values were observed for the thermal sum of the culture cycle, since the temperature values above the optimum were frequent $\left(25^{\circ} \mathrm{C}\right)$, Figure 1

In Table 9, the average values of hybrids and sowing dates are displayed for grain yield. For Hyola 61 and Hyola 575CL hybrids, there was no statistical difference between sowing dates, ranging from 512.70 to $637.04 \mathrm{~kg} \mathrm{ha}^{-1}$ and 717.50 to 869.75 $\mathrm{kg} \mathrm{ha}{ }^{-1}$, respectively. Hyola 50 and Hyola 433 showed higher grain yield in the first sowing date, with 711.27 and $932.27 \mathrm{~kg} \mathrm{ha}^{-1}$, respectively.

Table 9. Grain yield of five canola hybrids in three sowing dates.

\begin{tabular}{lccc}
\hline \multirow{2}{*}{ Hybrids } & \multicolumn{3}{c}{ Sowing dates } \\
\cline { 2 - 4 } & $03 / 03$ & $03 / 10$ & $03 / 17$ \\
\hline Hyola 50 & $711.27 \mathrm{bA}$ & $443.57 \mathrm{cB}$ & $437.50 \mathrm{cB}$ \\
Hyola 61 & $628.58 \mathrm{bA}$ & $512.70 \mathrm{cA}$ & $637.04 \mathrm{bA}$ \\
Hyola 433 & $932.27 \mathrm{aA}$ & $713.24 \mathrm{bB}$ & $725.63 \mathrm{bB}$ \\
Hyola 571CL & $745.55 \mathrm{bB}$ & $965.65 \mathrm{aA}$ & $439.60 \mathrm{cC}$ \\
Hyola 575CL & $869.75 \mathrm{aA}$ & $717.50 \mathrm{bA}$ & $844.73 \mathrm{aA}$ \\
\hline
\end{tabular}

Means followed by the same lowercase letter in the column and upper case in the row do not differ statistically from each other according to Scott-Knot test at 0.001 probability.

In the first sowing date, Hyola 433 and Hyola 575CL stood out, being statistically the same. In the second, the best performance was for Hyola $571 \mathrm{CL}$ and in the third for Hyola 575CL.

In the present work, grain yield was below the 2017 national average, $1,552 \mathrm{~kg} \mathrm{ha}^{-1}$ (CONAB, 2017). However, in places with similar soil and climatic conditions, such as in Mato Grosso do Sul, grain yield of $969 \mathrm{~kg} \mathrm{ha}^{-1}$ was found by Tomm (2007) for Hyola 61 and by Ito et al. (2014) an average yield of $687 \mathrm{~kg} \mathrm{ha}^{-1}$ for Hyola 571CL, 798 $\mathrm{kg} \mathrm{ha}^{-1}$ for Hyola 61 and $1,341 \mathrm{~kg} \mathrm{ha}^{-1}$ for Hyola 433. This is justified due to the low plant population (Table 3) and possibly by temperatures above $27^{\circ} \mathrm{C}$ during flowering (Figure 1), which associated with water deficit reduce this phase duration, causing grain yield reduction due to the abort of flowers and pod (MENDONÇA et al., 2016; TOMM et al., 2009b).

Although there is an association between decreased grain yield and flower abortion, Battisti et al. (2013), studying flowers dynamics and flowers abortion for canola and brown mustard hybrids in Santa Maria - RS, pointed out that there was no clear relationship between yield and flower total emission rate.

In different oilseeds, it has been observed a discrepancy in grains yield, which may originate from genotype, plant density and nitrogen fertilization, and the effects provided by the crop year influences production more than the cultivar potential. In addition, among the factors related to the environment, improved crop management can provide beneficial effects on grain yield (KRÜGER et al., 2011).

In the edaphoclimatic conditions of this study, in the year of 2017, the best agronomic performance was observed in the first sowing date for the canola hybrids Hyola 433 and Hyola 575CL and in the second sowing date for the canola hybrid Hyola 571CL.

RESUMO: Canola (Brassica napus L. var oleífera) é uma cultura de potencial devido a crescente demanda mundial por óleo vegetal. Diante disso, objetivou-se com este trabalho avaliar o desempenho de cinco híbridos de canola, em três épocas de semeadura em Jataí-GO. O experimento foi conduzido em delineamento 
de blocos casualizados, com parcelas subdivididas com quatro repetições. Nas parcelas foram avaliadas as três épocas de semeadura (03/03, 10/03 e 17/03) e nas subparcelas os híbridos (Hyola 50, Hyola 61, Hyola 433, Hyola 571CL e Hyola 575CL) no ano de 2017. Foram avaliadas: emergência de plântulas, populações inicial e final, florescimento, maturação, altura de planta, índice de sobrevivência de plantas e produtividade de grãos. Com os dados fenológicos foi realizado o cálculo da soma térmica. Foram efetuadas as análises de variância e as médias foram comparadas pelo teste de Scott Knott a 5\% de probabilidade. Para o índice de sobrevivência, destacaram-se os híbridos Hyola 433, Hyola 571CL e Hyola 575CL. A produtividade variou de acordo com híbrido e época. Nas condições edafoclimáticas deste estudo, no ano de 2017, o melhor desempenho agronômico foi observado na primeira época de semeadura para os híbridos de canola Hyola 433 e Hyola $575 \mathrm{CL}$ e na segunda época de semeadura para o híbrido de canola Hyola 571CL.

PALAVRAS-CHAVE: Brassica napus L. var oleífera. Fenologia. Produtividade. Tropicalização.

\section{REFERENCES}

ANGADI, S. V.; CUTFORTH, H. W.; MILLER, P. R.; MCCONKEY, B. G.; ENTZ, M. H.; BRANDT, A.; OLKMAR, K. M. Response of three Brassica species to high temperature stress during reproductive growth. Canadian Journal of Plant Science, Ottawa, v. 80, n. 4, p. 693-701, 2000. https://doi.org/10.4141/P99-152.

ARNOLD, C.Y. Maximum-minimum temperatures as a basis for computing heat units. Proceedings of the American Society for Horticultural Sciences, Stanford, v. 76, n. 1 p. 682-692, 1960. Available from: $<$ https://www.cabdirect.org/cabdirect/abstract/19610305608>.

ARRUÁ, A. M.; DUARTE JÚNIOR, J. B.; DA COSTA, A. C. T.; MEZZALIRA, E. J.; PIVA, A. L.; SANTIN, A. Características agronômicas e teor de óleo da canola em função da época de semeadura. Revista Brasileira de Engenharia Agrícola e Ambiental, Campina Grande, v. 18, n. 9, p. 934-938, 2014. https://doi.org/10.1590/1807-1929/agriambi.v18n09p934-938.

BANDEIRA, T. P.; CHAVARRIA, G.; TOMM, G. O. Desempenho agronômico de canola em diferentes espaçamentos entre linhas e densidades de plantas. Pesquisa Agropecuária Brasileira, Brasília, v. 48, n. 10, p. 1332-1341, 2013. https://doi.org/10.1590/S0100-204X2013001000004.

BATTISTI, R.; PILAU, F. G.; SCHWERZ, L.; SOMAVILLA, L.; TOMM, G. O. Dinâmica floral e abortamento de flores em híbridos de canola e mostarda castanha. Pesquisa Agropecuária Brasileira, Brasília, v. 48, n. 2, p. 174-181, 2013. https://doi.org/10.1590/S0100-204X2013000200007.

BRASIL. Portaria 326/2012 de 13 de Dezembro de 2012. Diário Oficial da União, Brasília, 17 set. 2012 , seção 1, p. 5924 - 5925.

CHAVARRIA, G.; TOMM, G. O.; MULLER, A.; MENDONÇA, H. F.; MELLO, N.; BETTO, M. S. Índice de área foliar em canola cultivada sob variações de espaçamento e de densidade de semeadura. Ciência Rural, Santa Maria, v. 41, n. 12, p. 2084-2089, 2011. https://doi.org/10.1590/S0103-84782011001200008.

Companhia Nacional de Abastecimento - CONAB. Acompanhamento da safra brasileira de grãos. Observatório Agrícola, v. 4, n. 6, p. 1-176, 2017. Available from: < https://www.conab.gov.br>. Accessed date: 2 Jun. 2017.

Companhia Nacional de Abastecimento - CONAB. Acompanhamento da safra brasileira de grãos. Observatório Agrícola, v. 1, n. 1, p. 1-129, 2018. Available from: $<$ https://www.conab.gov.br $>$. Accessed date: 2 Jun. 2017.

DALMAGO, G. A.; CUNHA G. R.; TOMM, G. O.; SANTI, A.; PIRES, J. L. F. Canola. In: MONTEIRO, J. E. B. A. Agrometeorologia dos cultivos: o fator meteorológico na produção agrícola. Brasília, DF: INMET, 2009. p. 131-149. 
EDWARDS, J.; HERTEL, K. Canola growth and development. . New South Wales: Department of Primary

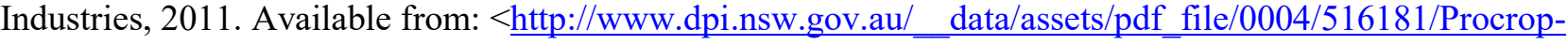
canola-growth-and-development.pdf $>$. Accessed date: 20 jan. 2019.

Empresa Brasileira de Pesquisa Agropecuária (EMBRAPA). Definição e histórico de Canola. Passo Fundo: Embrapa Trigo. 2017. Available from: < http://www.cnpt.embrapa.br/culturas/canola/definicao.htm>. Accessed date: 2 Jun. 2017.

FOCHESATTO, E. Fenologia da colza em diversos ambientes no Rio Grande do Sul. 2012. 54 f. Relatório de estágio (Curso de Graduação em Agronomia), Instituto de Desenvolvimento Educacional do Alto UruguaiIDEAU, 2012.

HANSON, B. K.; JOHNSON, B. L.; HENSON, R. A.; RIVELAND, N. R. Seeding rate, seeding depth, and cultivar influence on spring canola performance in the Northern Great Plains. Agronomy Journal, Madison, v. 100, n. 5, p. 1339-1346, 2008. https://doi.org/10.2134/agronj2007.0034

HRCHOROVITCH, V. A.; RIBEIRO, R. A.; SULZBACHER, J. B. W.; POSSENTI, J. C.; DOMINGUES, L. D. S.; TOMM, G. O. Efeito de épocas de semeadura nas características fenométricas de híbridos de canola. In: SIMPÓSIO LATINO AMERICANO DE CANOLA, 1, Passo Fundo, 2014. Anais... Brasília, DF: Embrapa, 2014. p. 1-5.

IRIARTE, L. B.; VALETTI, O. E. Cultivo de colza. Buenos Aires: Instituto Nacional de Tecnologia Agropecuária - INTA, 2008. Available from:

$<$ http://www.acopiadores.com/sites/default/files/gacetillas/14Liliana\%20Iriarte\%20\%20Cultivos\%20de\%20Colza 590398.pdf>. Accessed date: 20 jan. 2019.

ITO, M. A.; DA SILVA, C. J.; FABRIS, D. D. N.; TOMM, G. O. Efeito de épocas de semeadura sobre o desempenho de genótipos de canola em Dourados, MS. In: SIMPÓSIO LATINO AMERICANO DE CANOLA, 1, Passo Fundo, 2014. Anais... Brasília, DF: Embrapa, 2014. p. 1-5.

Instituto Nacional De Meteorologia (INMET). Banco de dados meteorológicos para ensino e pesquisa, 2017. Available from: $<$ https://bdmep.inmet.gov.br $>$. Accessed date: 2 Jun. 2017.

KRÜGER, C. A. M. B.; DA SILVA, J. A. G.; MEDEIROS, S. L. P.; DALMAGO, G. A.; GAVIRAGHI, J. Herdabilidade e correlação fenotípica de caracteres relacionados à produtividade de grãos e à morfologia da canola. Pesquisa Agropecuária Brasileira, Brasília, v. 46, n. 12, p. 1625-1632, 2011.

https://doi.org/10.1590/S0100-204X2011001200007.

LUZ, G. L.; MEDEIROS, S. L. P.; TOMM, G. O.; BIALOZOR, A.; DISCHKALN, A. A.; PIVOTO, D. Temperatura base inferior e ciclo de híbridos de canola. Ciência Rural, Santa Maria, v. 42, n. 9, p.1549-1555, 2012. https://doi.org/10.1590/S0103-84782012000900006.

MENDONÇA, J. A.; RIBOLDI, L. B.: SOARES, C. D. F.; CASTRO, P. R. C.; KLUGE, R. A. Canola (Brassica napus L.). Piracicaba: ESALQ - Divisão de Biblioteca, 2016. Available from: <

https://www.esalq.usp.br/biblioteca/sites/default/files/publicacoes-a-venda/pdf/SPR61.pdf $>$. Accessed date: 2 Jun. 2017.

MONTEIRO, J.E.B.A. Agrometeorologia dos cultivos: o fator meteorológico na produção agrícola. Brasília: Instituto Nacional de Meteorologia - INMET, 2009. Available from: <

https://www.embrapa.br/documents/1355291/37056285/Bases+climatol\%C3\%B3gicas_G.R.CUNHA_Livro_A grometeorologia + dos + cultivos.pdf/13d616f5-cbd1-7261-b157-351eaa31188d?version=1.0 $>$. Accessed date: 2 Jun. 2017. 
MORI, C.; TOMM, G.O.; FERREIRA, P. E. P. Aspectos econômicos e conjunturais da cultura da canola no mundo e no Brasil. Passo Fundo: Embrapa Trigo, 2014. Available from: < http://www.cnpt.embrapa.br/biblio/do/p do149.htm>. Accessed date: 8 Jun. 2017.

MORRISON, M. J.; MCVETTYI, P. B. E.; SHAYKEWICH, C. F. The determination and verification of a baseline temperature for the growth of Westar summer rape. Canadian Journal Plant Science, Ottawa, v. 69, n. 2, p. 455-464, 1989. https://doi.org/10.4141/cjps89-057

NANDA, R.; BHARGAVA, S. C.; RAWSON, H. M. Effect of sowing date on rates of leaf appearance, final leaf numbers and areas in Brassica campestris, B. juncea, B. napus and B. carinata. Field Crops Research, Netherlands, v. 42, n. 2, p. 125-134, 1995. https://doi.org/10.1016/0378-4290(95)00026-M.

NIED, A. H. Parâmetros bioclimáticos e resposta da canola ao ambiente físico. 2013. 135 f. Tese. (Doutorado em Fitotecnia) - Faculdade de Agronomia, Universidade Federal do Rio Grande do Sul, Porto Alegre, 2013.

RIGON, C. A. G.; GOERGEN, A. B.; BORDIN, R.; PILlA, R. B.; ZANATTA, T. P.; DA SILVA, V. R.; TOMM, G. O. Características agronômicas, rendimento de óleo e proteína de canola em diferentes épocas de semeadura. Revista Brasileira de Tecnologia Agropecuária, Frederico Westphalen, v. 1, n. 2, p. 124-132, 2017. Available from: < http://revistas.fw.uri.br/index.php/rbdta/article/view/2535/2525>.

SHAHIN, Y.; VALIOLLAH, R. Effect of row spacing and seeding rates on some agronomical traits of spring canola (Brassica napus L.) cultivars. Journal of Central European Agriculture, Croácia, v. 10, n. 1, p. $115-$

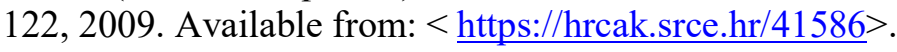

STRECK, N. A. A generalized nonlinear air temperature response function for node appearance rate in muskmelon (Cucumis melo L.). Revista Brasileira de Agrometeorologia, Santa Maria, v. 10, n. 1, p. 105-111, 2002.

TAN, X. L.; KONG, F. M.; ZHANG, L. L., Juan, L.; CHEN, S.; QI, C. K. Cloning and Analysis of Hemoglobin Gene in Cyanobacterium and Transformation into Brassica napus. Acta Agronomica Sinica, China, v. 35, n. 1, p. 66-70, 2009. https://doi.org/10.3724/SP.J.1006.2009.00066.

TESFAMARIAM, E. H. Modelling the soil water of canola Brassica napus L (Hyola 60). 2004. 135 f. Dissertação (Mestrado) - Department of Plant Production and Soil Sience, Faculty of Natural and Agricultural Science, University of Pretoria, Pretoria, 2004.

THOMAS, P. The Growers' manual. Winnipeg: Canola Council of Canada, 2003. Available from:

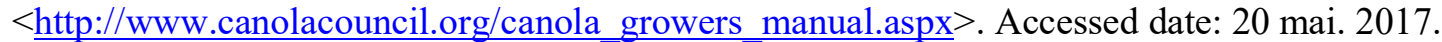

TOMM, G.O.; FERREIRA, P.E.P. Canola híbridos convencionais e com resistência a Clearfield ${ }^{\circledR}$. Available from: < https://ainfo.cnptia.embrapa.br/digital/bitstream/item/142262/1/ID43652-2016FD394.pdf >. Accessed date: 20 mai. 2017.

TOMM, G. O.; FERREIRA, P. E. P.; VIEIRA, V. M. Canola: Híbridos avaliados em rede coordenada pela Embrapa. Passo Fundo: Embrapa Trigo, 2014. Available from: < https://www.embrapa.br/en/web/mobile/publicacoes/-/publicacao/1020028/canola-hibridos-avaliados-em-redecoordenada-pela-embrapa $>$. Accessed date: 8 Jun. 2017.

TOMM, G.O. Indicativos tecnológicos para produção de canola no Rio Grande do Sul. Passo Fundo: Embrapa Trigo, 2007. Available from: < https:/www.embrapa.br/en/busca-de-publicacoes//publicacao/821535/indicativos-tecnologicos-para-producao-de-canola-no-rio-grande-do-sul>. Accessed date: 20 mai. 2017. 
TOMM, G. O.; WIETHÖLTER, S.; DALMAGO, G. A.; SANTOS, H. D. Tecnologia para produção de canola no Rio Grande do Sul. Passo Fundo: Embrapa Trigo, 2009a. Available from: <

https://www.embrapa.br/en/busca-de-publicacoes/-/publicacao/852550/tecnologia-para-producao-de-canola-norio-grande-do-sul >. Accessed date: 20 mai. 2017.

TOMM, G. O.; FERREIRA, P. E. P.; DE AGUIAR, J. L. P.; DE CASTRO, A. M. G.; LIMA, S. M. V.; MORI, C. Panorama atual e indicações para aumento de eficiência da produção de canola no Brasil. Passo Fundo: Embrapa Trigo, 2009b. Available from: < http://www.cnpt.embrapa.br/biblio/do/p do118.htm>. Accessed date: 10 Jun. 2017.

TOMM, G. O.; TRENNEPOHL, J., BONI, A., PESSATO, J., MORRIS, H.; TATSCH, R. Desempenho de genótipos de canola no Mato Grosso do Sul, 2006. Embrapa Trigo-Boletim de Pesquisa e Desenvolvimento (INFOTECA-E), 2007. Available from: <

http://www.diadecampo.com.br/zpublisher/materias/Materia.asp?id=19851\&secao=Pacotes+Tecnol\%F3gicos $>$. Accessed date: 10 Jun. 2017.

USDA. United States Departament of Agriculture. Economic Reserch Service. Canola. Available from: < https://www.ers.usda.gov/topics/crops/soybeans-oil-crops/canola.aspx $>$. Accessed date: 26 Jun. 2017. 